\title{
Fra modermælk til donormælk
}

Forhandlinger af mælk, individ og velfxrdskollektiv

Julie Borring ${ }^{1}$, Ditte Seidler Hansen², Mie Seest Dam³ \& Mette Nordahl Svendsen ${ }^{4}$

${ }^{1}$ cand. scient. san. publ, Københavns Universitet

julieborrings@gmail.com

${ }^{2}$ cand. scient. san. publ, Københavns Universitet

ditte_seidler@hotmail.com

${ }^{3}$ Afdeling for Sundhedstjenesteforskning, Københavns Universitet mda@sund.ku.dk

${ }^{4}$ Afdeling for Sundhedstjenesteforskning, Københavns Universitet mesv@sund.ku.dk

- Delt førsteforfatterskab -

Borring, Julie; Hansen, Ditte Seidler; Dam, Mie Seest; Svendsen, Mette Nordahl (2018). 'Fra modermælk til donormælk: Forhandlinger af mælk, individ og velfærdskollektiv' i Tidsskrift for Forskning i Sygdom og Samfund, nr. 29, 99-119.

Denne artikel udforsker de socio-materielle praksisser, der etablerer donormælk som en sikker substans, der kan cirkulere inden for det danske velfærdssamfund. Studiet tager afsæt $i$ etnografisk feltarbejde i Kvindemælkcentralen på Hvidovre Hospital, hvor arbejdet med donormælk til danske neonatalafdelinger foregår. Det er en arbejdsplads med få ansatte, men med et slutprodukt, som er af livsvigtig karakter for præmature børn, hvis mødre ofte har svært ved at etablere en mælkeproduktion, særligt de første dage efter fødsel. Med inspiration fra ideen om multipel topologi samt antropologiske studier af forbundethed analyserer artiklen hoilke forhold, der gør udvekslingen af mælk fra donormødre til præmature børn mulig. På baggrund af interviews med personale, donormødre 
og mødre til for tidligt fødte børn viser vi, hvordan de ansatte $i$ Kvindemælkcentralen arbejder med at præsentere donormælk som både en naturlig kropslig substans og et standardiseret produkt uden spor af donorens krop. Artiklen giver indsigt $i$ donernes placering $i$ et forpligtende fxllesskab forvaltet af Kvindemælkcentralen og demonstrerer samtidig Kvindemælkcentralens centrale position $i$ arbejdet med at hjælpe præmature og syge børn. Vi argumenterer for, at Kvindemælkcentralens ansatte forvalter, balancerer og afgrænser kontakten mellem donor og modtager - et arbejde, som gør det muligt for modermælk at cirkulere og forbinde nyfødte borgere til velfærdskollektivet.

\section{From breastmilk to donor milk}

This article examines the socio-material practices which establish donor milk as a safe substance that can circulate within the Danish welfare society. The study is based on ethnographic fieldwork in the human donor milk bank, Kvindemælkcentralen, at Hvidovre Hospital, in which the work with donor milk for Danish neonatal departments takes place. It is a workplace with few employees, however, the final product is of vital importance to premature children, whose mothers often struggle to establish a milk production, especially during the first days after giving birth. With inspiration from the idea of multiple topology and anthropological studies of relatedness this article analyzes the factors that facilitate the exchange of milk for premature children. Based on interviews with staff, donor mothers, and mothers of premature children we illustrate how the staff at Kvindemalkcentralen aim to present donor milk as a natural bodily substance as well as a standardized product free from traces of the donor's body. The article provides insight into the donors' placement in a committed community managed by Kvindemalkcentralen, and at the same time demonstrates the central position of Kvindemalkcentralen in their work of helping premature and sick children. We argue that the staff at Kvindemælkcentralen manages and balances the contact between donor and recipient. Through their work, boundaries between donors and recipients are established, which in return allows for breast milk to circulate and link newborn citizens to the welfare state.

\section{Prioritering af børneliv}

Kvindemælkcentralen på Hvidovre Hospital er den største af to mælkebanker i Danmark. Det er en arbejdsplads med kun fire fuldtidsansatte, men med et slutprodukt, som er af livsvigtig karakter for både præmature og syge nyfødte børn. Kvindemælkcentralens opgave er at sikre forsyning af donormælk til danske neo- 
natalafdelinger. Velfærdsstatens prioritering af børneliv står centralt i dette arbejde, som er næsten usynligt for offentligheden.

Prioritering af børneliv i den vestlige verden er et forholdsvist nyt fænomen. På baggrund af et amerikansk materiale argumenterer sociolog Viviana Zelizer (1985) for, at børns værdi ændrede sig i perioden mellem 1870erne og 1930erne. Zelizer beskriver denne forandring som en kulturel proces, der førte til en helliggørelse (sacrilization) ${ }^{1}$ af børns liv. Ifølge Zelizer havde børns værdi i det 19. århundrede økonomisk og produktiv karakter, hvorimod børns værdi i det 20. århundrede har en følelsesmæssig karakter. Det 20. århundredes barn er økonomisk værdiløst, men følelsesmæssigt uvurderligt. Dette skift i den vestlige verdens opfattelse af børns værdi foregår samtidig med en national prioritering af folkesundhed og interventioner rettet mod at nedbringe børnedødeligheden.

Etableringen af mælkebanker i Skandinavien i slutningen af 1930erne og i 1940erne kan ses som en konsekvens af prioritering af børneliv i lyset af den på den tid nyfundne indsigt i modermælkens helbredende egenskaber (J. Pedersen 1982, 300-1). Udviklingen af brystpumpen muliggjorde transport af modermælk væk fra den ammende krop, og modermælk var således ikke længere begrænset til en intim hud-mod-hud udveksling mellem mor og barn (Boyer, 2010, s. 5).

Brugen af donormælk er i dag en veletableret praksis på danske neonatalafdelinger, men før det er muligt for modermælken at rejse fra den ammende krop, kræver det mobilisering og opretholdelse af et komplekst socio-teknisk netværk af genstande og aktører (Boyer, 2010, s. 10). I denne artikel udforsker vi, hvordan Kvindemælkcentralen transformerer modermælk til donormælk og derved indtager en central position i arbejdet med at hjælpe præmature og syge børn. Vi vil i artiklen have fokus på de udvekslinger, som etableres for at holde børn i live og undersøge, hvordan en kropslig substans, som mælk, kan etablere relationer og skabe forbindelser mellem individ og velfærdskollektiv.

\section{Kvindemælkcentralen}

Kvindemælkcentralen var den første mælkebank i Danmark og blev oprettet i 1943 på Børnehospitalet Fuglebakken på Frederiksberg (Pedersen 1982, 300-1) (Arnold 1999, 55). Da Fuglebakken lukkede i 1983, flyttede børneafdelingen og dermed også Kvindemælkcentralen til dens nuværende lokalitet på Hvidovre Hospital, hvorfra mælken sælges til bl.a. neonatalafdelingerne på Hvidovre Hospital, Rigshospitalet, Herlev Hospital, Holbæk Sygehus og Roskilde Sygehus samt til Island, 
Færøerne og Grønland. Prisen for en liter donormælk er 1.000 kr. eller 1.700 kr. alt efter, hvor meget protein donormælken indeholder. Mødrene, som donerer den rå modermælk, betales 196 kr. pr. liter, de donerer. ${ }^{2}$ Pengene udbetales så snart, mælken benyttes som donormælk.

Ernæring spiller en stor rolle på de danske neonatalafdelinger, hvor modermælk udgør den vigtigste kilde til ernæring for præmature børn. Dog er det ofte en udfordring for mødre til præmature børn at etablere en tilstrækkelig stor mælkeproduktion, særligt de første dage efter fødslen. Derfor er det nyfødte præmature barn i mange tilfælde afhængigt af ernæring fra andre kvindekroppe. I Danmark er donormælk det foretrukne alternativ til mors egen mælk - særligt til de helt små (Sundhedsstyrelsen 2016, 35). Donormælk besidder mange af de samme forebyggende egenskaber som modermælk. Blandt andet indeholder mælken aktive enzymer, der fremmer modningen af barnets tarme og har antiinflammatoriske egenskaber, som beskytter den nyfødte mod infektion (Boyd, Quigley og Brocklehurst 2007, 169). Donormælk kan dog ikke sidestilles med modermælk, da denne mælk ofte kommer fra mødre, som har et ældre barn, dog er barnet maksimalt otte uger gammelt, når mødrene starter som mælkedonorer. I modsætning til den første mælk er denne mere modne mælk mindre proteinrig og mindre rig på bioaktive stoffer.

Modermælk krydser forskellige grænser i sin transformation til donormælk. Den rejser fra privat hjem til hospital, fra kvindekrop til fremmed barn og fra at være substans uden pris til prissat ernæring. I det følgende udfolder vi det netværk af aktører og praksisser, som etablerer disse skift og får mælken til at blive en cirkulerbar substans, der skaber forbundethedsrelationer mellem borger og velfærdskollektiv.

\section{Modermælkens transformation og dens form i forskellige rum}

For at forstå hvordan modermælk transformeres til donormælk, må vi se på de konkrete praksisser, som den indgår i. I studier af aterosklerose samt anæmi synliggør Annemarie Mol (Mol, The Body Multiple 2002) sammen med John Law (Mol og Law 1994), hvorledes et objekt kan skifte form uden at ødelægges. Objekter er ifølge Mol multiple, idet de ikke har en iboende betydning, men praktiseres forskelligt i forskellige sammenhænge. En opmærksomhed på selve transforma- 
tionen af substansen hjælper til at flytte fokus fra selve objektet til de materielle praksisser og relationer, som objektet befinder sig i. Mol og Law argumenterer i deres artikel om anæmi for, at "the social' does not exist as a single spatial type, but rather performs itself in a recursive and topologically heterogeneous manner" og henviser her til en multipel topologi (Mol og Law 1994, 641). Begrebet multipel topologi referer til forskellige rumlige konfigurationer: rum som en afgrænset region, rum som relaterede netværk og rum som flydende strømme. Med udgangspunkt i ideen om multiplicitet undersøger vi i det følgende hvilken form og betydning, som mælken får i forskellige sociomaterielle relationer. På denne måde undersøger vi, hvordan modermælk praktiseres, forhandles og transformeres til donormælk i et socio-teknisk netværk af genstande og aktører i felten. Hvordan kan mælken i sin transformation forandre og etablere nye relationer? Hvilke former for forbindelse etableres i denne proces?

Janet Carsten benytter begrebet forbundethed til at angive måder, hvorpå mennesker forstår og praktiserer relationer (Carsten 1995, 224). Som analytisk begreb hjælper forbundethed til at undersøge og forstå, hvordan relationer mellem mennesker skabes i forskellige sociale sammenhænge (Carsten 2000, 4). I denne artikel bruger vi begrebet til at udforske hvilke forestillinger om forbundethed, som transformationen af modermælk til donormælk aktualiserer, og hvordan relationer og fravær af relationer etableres i denne transformation.

\section{Det etnografiske feltarbejde}

Denne artikel tager sit afsæt i et empirisk materiale, som er genereret i perioden fra juni til november 2016. Det etnografiske feltarbejde, foretaget af de to første forfattere (Borring og Hansen), består af deltagerobservation i Kvindemælkcentralen på Hvidovre Hospital og 16 semistrukturerede interviews med personalet i Kvindemælkcentralen, mælkedonorer og mødre til børn født for tidligt. Artiklens sidste-forfattere (Dam og Svendsen) har udført forskning om sociale og etiske aspekter af ernæring til nyfødte både i klinisk og eksperimentel neonatologi og bidrager med deres viden og erfaring fra denne forskning.

Borring og Hansens interviews med donormødre fandt sted i umiddelbar forlængelse af mødrenes indledende samtale med personalet i Kvindemælkcentralen, som førsteforfatterne også overværede og var en del af. Det betød, at Borring og Hansen i feltarbejdsperioden kontinuerligt besøgte Kvindemælkcentralen, havde uformelle samtaler med personalet og fik indblik i personalets håndte- 
ring af donormælken og personalets interaktion med donormødrene. Da mange af donormødrene selv havde været indlagt på neonatalafdelingen og modtaget donormælk til deres præmature barn, gav interviewene indblik i erfaringer med udveksling af mælk fra både donors og modtagers perspektiv. Alle informanter optræder i artiklen under pseudonym bortset fra Anne Olin, der efter eget ønske optræder ved navn.

\section{Mælk som naturlig flydende væske og målbar substans}

Donation af modermælk er udelukkende muligt for mødre, som lige har født, og som har en såkaldt "naturlig" overproduktion af mælk. Et naturligt overskud defineres af Kvindemælkcentralen som et overskud på minimum $200 \mathrm{ml}$ i døgnet udover det, som morens eget barn har behov for. I et interview forklarer leder af Kvindemælkcentralen, Anne Olin, hvorfor hun lægger vægt på, at overskuddet af mælk skal være "naturligt":

"Vi vil gerne være sikre på, at de [donormødrene] ikke sidder og bruger en masse tid og kræfter på at levere mælk til os - mælk som går fra deres eget barn. Så der er nogle mødre, der egentlig bliver sådan lidt 'Nå, vil I ikke have det?'. Og det er jo egentlig med vilje, fordi vi ved, at det er et stort arbejde at malke ud - og malke ud mange gange om dagen." (Interview med Anne Olin, leder af Kvindemælkcentralen, den 3/6 20160.)

I interviewet med Anne Olin indebærer naturligt overskud, at mælken flyder ubesværet. Samtidig italesætter hun også udmalkningen som et potentielt møjsommeligt arbejde, der ikke må gå ud over mor-barn forholdet eller fratage donorens eget barn sin mors mælk. Kategorien "naturligt overskud" balancerer dermed mælk til donormorens eget barn og mælk til de præmature børn på neonatalafdelingen.

Donormødre, som oplever et naturligt overskud af mælk, er tvunget til at malke mælken ud for at forebygge brystbetændelse. Ofte har de malket så meget mælk $\mathrm{ud}$, at de ikke har plads til den fysisk. Mælken fylder op i deres frysere og bliver et irritationsmoment. Men de ønsker ikke at smide den ud - de nænner det ikke. For eksempel fortæller Majken og Marianne: 
"Altså jeg kan ikke finde ud af at smide mælken ud. Min mand har sagt: 'Kan du ikke bare smide den ud nu.' Det kan jeg ikke (...) Det er jo både fordi, at det er hårdt arbejde, og så er det selvfølgelig også fordi, at det har noget med at være mor at gøre, og at man på en eller anden måde har en tilknytning. At det er et stykke af en selv, man giver videre." (Interview med Majken, donormor, den 28/6 2016).

"Det er jo en gene, når der kommer så meget mælk, at det bliver et problem for min datter og for mig. Men jeg tænker, at det bare er sådan, det er. Der er jo ikke så meget at gøre. Jeg tror bare, at jeg er sådan en, som producerer meget mælk, og så kan det lige så godt gå til et fornuftigt sted (...) Jeg synes klart, at det skal bruges til noget." (Interview med Marianne, donormor, den 4/8 2016).

På den ene side ses mælken som noget meget værdifuldt for mødrene, som de ikke bare kan skille sig af med - noget som er "forkert" at smide ud. På den anden side betragtes mælken som et overskudsprodukt, der enten bare tager plads i fryseren, eller som er til gene for moderen. Catherine Waldby og Robert Mitchell, argumenterer i deres bog Tissue Economies: Blood, Organs, and Cell Lines in Late Capitalism fra 2006 for, at visse biosubstanser kan forstås som affald, gave og/eller råvare alt efter omstændighederne. Affald, der ses som det modsatte af værdi i én sammenhæng, kan blive tillagt betydelig værdi i en anden (Waldby \& Mitchell, 2006, s. 84). I mødet med Kvindemælkcentralen italesættes donormødrenes mælk som et "naturligt overskud" - en substans, som flyder naturligt. Modermælken kan i denne forstand ses som affald. Et overskud som mødrene ikke har behov for til eget barn, og som de ikke fysisk har plads til, fordi overskuddet er så stort, og som må genplaceres for at få værdi igen. Hvor modermælken, før det blev muligt at transportere den fra den ammende krop og transformere den til donormælk, enten blev kasseret eller brugt til børn i ens omgangskreds, bliver mælken nu anset som noget, der kan benyttes som en ressource.

Ligeledes oplevede Borring og Hansen under deres feltarbejde, hvordan donormælken kan flyde til andre børn som en form for bearbejdelse i en sorgproces. En kvinde havde født et maturt barn, som døde kort efter fødslen. Hun ringede til Kvindemælkcentralen med ønske om at donere sin mælk. Rikke, én af de ansatte i Kvindemælkcentralen, fortæller, at i sådanne tilfælde tager Kvindemælkcentralen imod mælken uden først at gennemgå de vante procedurer og forholdsregler, som den indledende samtale og blodprøvetagning. Det rigtige i denne situation bliver at hjælpe kvinden med at skabe mening i hendes store tab. Personalet i Kvinde- 
mælkcentralen tolker donationen som en lindrende omstændighed for kvinden, og i dette tilfælde bliver praktiseringen af "naturligt overskud" et moralsk forhold frem for et spørgsmål om mængde og kvalitet af mælk. Kvinden, som så tragisk har mistet sit eget barn, får derved mulighed for at lade sin modermælk flyde til andre børn, der har brug for den samt mulighed for at omdanne en nu ubrugelig substans for hende til en værdifuld gave for skrøbelige børn og deres forældre. Substansen lader sig ikke afgrænse af bestemte lokaliteter, men flyder frit og indgå i nye relationer, uden at de gode værdier i modermælken ødelægges.

Kvindemælkcentralen fastholder en lang dansk tradition for at betale mødre for deres modermælk. Så snart modermælken bliver en del af Kvindemælkcentralens rum, bliver den til en substans, som skal måles, vejes og prissættes, og denne praksis viser sig at være central for modermælkens transformation fra affald til ressource. I dette rum opfattes mælken ikke længere som modermælk, men som bankmælk, og mælken må igennem en række tjekpoints, før den kan flyde fra donor til modtager. Borring og Hansen oplever under deres feltarbejde, at mælken på denne del af sin rejse antager form som en vare, der bliver handlet med, og som har en økonomisk værdi. Dette kom først og fremmest til udtryk ved, at udmalkningen betragtes som et arbejde af både Kvindemælkcentralens medarbejdere og af de ammende mødre. Et arbejde man i Danmark bliver betalt for at udføre. Ifølge Høyer, der blandt andet har koncentreret sin forskning om etik som reguleringsform og udvekslingssystemer for kropsligt materiale, vil betaling for at donere eksempelvis en knogle resultere i en forventning om, at motivet for at donere er af økonomisk karakter (Høyer 2007). I Borring og Hansens empiri synes økonomisk og moralsk værdi dog ikke at stå i et modsætningsforhold. Samtlige af de donormødre, som vi møder, understreger, at deres mælkedonation er motiveret af et ønske om at gøre noget godt for andre. Den økonomiske gevinst tager således ikke noget fra den gode gerning. Da Borring og Hansen spørger Anne Olin om, hvorfor mødrene modtager penge for deres mælk, svarer hun: "Man må ikke donere mælk uden at få noget for det". Anne Olin illustrerer således et centralt værdisæt i Kvindemælkcentralen. Donormødre får betaling for deres mælk i Danmark og Sverige (Tully 1991, 146), og derved ser vi, at disse velfærdssamfund med den finansielle belønning til donorerne betragter udvekslingen af mælk for penge som rigtig og retfærdig. De norske nationale retningslinjer forbyder betaling for modermælken, men tillader at donoren kan kompenseres for de udgifter, hun har afholdt i denne forbindelse - eksempelvis udgifter til transport og elektricitet (Grøvslien og Grønn 2009, 208). Uanset om den økonomiske belønning kaldes betaling eller kompensation, ligger den på samme niveau i de tre lande. 
Alligevel oplevede Borring og Hansen gennem deres tilstedeværelse i Kvindemælkcentralen, at mælkens økonomiske værdi hele tiden holdes i skak. For eksempel taler personalet meget om, at det vigtigste ved deres arbejde er at være med til at give skrøbelige børn den bedste start på livet. I samtalerne med personalet fremstår mælken som en substans, der flyder over fra mor og kan opsamles af banken, hvorefter mælken flyder fra bank til modtager. I modsætning til denne flydende form indebærer betalingen, at modermælken fremstår som en målbar enhed, hvis mængde afgør et økonomisk beløb, som afslutter transaktionen mellem bank og donor, og som kun indirekte implicerer præmature og syge børn.

De opstillede kriterier fra Kvindemælkcentralen for hvad, der kan udgøre den ressource, som er fundamental for det for tidligt fødte barns udvikling, sætter grænser for, hvad der kan doneres til banken. Når først moderen er godkendt af Kvindemælkcentralen opstår et fleksibelt rum, hvor mælken flyder ubesværet og grænseløst fra donormoren til Kvindemælkcentralen, indtil moderen ikke længere har en overproduktion af mælk, eller mælkens proteinindhold er for lavt. Samtidig ser vi, hvordan mælken etableres som en målbar ressource gennem hårdt arbejde $\mathrm{i}$ form af udmalkning. Modermælk som substans kan således antage forskellige former (flydende substans og afgrænset mængde) og forskellige betydninger for aktørerne i felten. Mælkens flertydighed forvaltes af personalet $\mathrm{i}$ det lille køkken, som sikrer mælkens rette form i konkrete sammenhænge.

\section{Forvaltning af grænser fra modermælk til donormælk}

Under den indledende samtale med de kommende donormødre optager personalet en journal med henblik på at sikre kvaliteten af den donerede modermælk. Under samtalen bliver mødrene bedt om personlige oplysninger såsom navn og adresse, de bliver spurgt, om de tager nogen former for medicin, ryger eller drikker og endelig bliver de informeret om omstændigheder, hvor de ikke bør donere deres mælk. I forlængelse af samtalen skal donormødrene have taget en blodprøve. Blodet bliver kontrolleret for de vigtigste vira, som kan smitte både gennem blod og mælk.

Retningslinjerne for, hvilken mælk Kvindemælkcentralen ønsker at modtage, er meget strikse. Endda mere strikse end de officielle anbefalinger om ernæring til eget barn. Dette forhold kommer også til udtryk i interviewene med donormødre. De ser den donerede modermælk som mere værdifuld og knap end den mælk, de har i overflod til deres eget barn. For eksempel fortæller Louise: 
"Jeg tænker, at nu når jeg skal donere mælken, så vil jeg gøre mere ud af hygiejnen. Altså være mere opmærksom på det. (...) Jeg ved ikke hvorfor. Man tvivler måske lidt på sig selv, om man er ren nok. Og så selvfølgelig vil jeg jo gerne bare give det bedste. Fordi det skal gives til nogle, der måske ikke kan tåle så meget." (Interview med Louise, donormor, den 12/7 2016).

Louise vil gerne være "ren nok" og "give det bedste". Ligeledes fortæller andre donormødre, at de opdeler mælken i fryseren, så de er sikre på, at det kun er deres eget barn, der får den mælk, de har malket ud, mens de enten har haft brystbetændelse eller indtaget smertestillende medicin. Mødrene donerer den reneste mælk og beholder den mere forurenede mælk til eget barn. Denne tendens iagttager Katherine Carroll (2014) også i sit studie af donation af mælk i Nordamerika (Carroll 2014, 476). Mødrenes selvdisciplinering og moralske vurderinger er vigtige for at sikre mælkens anvendelighed på neonatalafdelingen, men også medvirkende til at give den donerede mælk en større ernæringsmæssig værdi sammenlignet med modermælken, som de giver til eget barn. Mælken flyder ikke blot, men inddeles $i$ et kvalitetshierarki.

Efter udmalkning er modermælken klar til at blive afhentet af Kvindemælkcentralens chauffør på donormødrenes private adresse. Chaufføren afhenter mælken frossen og transporterer den i en køletaske til Kvindemælkcentralen, hvor den igen kommer på frys. Transporten etablerer mælken som en vigtig substans, der prioriteres i sundhedsvæsnet, og som skal transporteres under særlige forhold. Den frosne mælk stilles til optøning i et døgn i køleskab inden, den forarbejdes. Den ældste mælk bliver optøet og brugt først. Når der er taget stikprøver af hver af donormødrenes mælk til bakteriekontrol, kontrolleres surhedsgraden, og derefter bliver mælken fra hver enkelt donormor hældt sammen i en målekolbe. Under feltarbejdet observerer Borring og Hansen, hvordan personalet hælder mælken gennem en si med gazebind, for at dyrehår mm. ikke ender i den færdige donormælk, samt hvordan personalet kontrollerer, om mælken er blevet blandet sammen eller fortyndet med andre væsker. Når den optøede mælk fra mødrene er hældt sammen i målekolben, tager personalet endnu en prøve for at registrere mælkens proteinniveau.

Personalet i Kvindemælkcentralen blander mælk fra tre til otte mødre, når de laver donormælk. Dette sikrer, at mælken bliver mere smagsmæssig neutral, og at antistofferne i mælken blandes, så en mere næringsmæssig robust mælk opnås. Den dag, vi observerer processen, blander personalet mælk fra fire donormødre. Mælken bliver rørt rundt med en stor automatisk røreske, der sikrer en ligelig for- 
deling af mælk og fedt. Derefter ser Borring og Hansen, hvordan mælken bliver ført via en slange og et doseringsapparat ned i plastikflasker. Mælken doseres til $200 \mathrm{ml}$ og kontrolvejes efterfølgende for at sikre, at det præcise antal $\mathrm{ml}$ er i flasken. Da al mælken er hældt på flasker, tager personalet endnu en bakterieprøve. Derefter hjælper Borring og Hansen med at stille flaskerne ned i en pasteuriseringsmaskine. Maskinen består af tre blokke, hvor der kan stå 12 flasker i hver. I hver blok er der en flaske med demineraliseret vand, som måler temperaturen i selve flasken. Mælken bliver varmebehandlet op til 64 grader og pasteuriseret i en halv time. Derefter bliver flaskerne nedkølet til 3-4 grader før, at flaskerne kan komme på frys. Når pasteuriseringsprocessen er færdig, og mælken har den rette temperatur, bliver der taget endnu en bakterieprøve af den pasteuriserede mælk. Hvis bakterieprøven testes positiv ompasteuriseres mælken.

Disse daglige procedurer er et udtryk for, at den mælk, der modtages, ikke altid kan betragtes som "ren". Så længe modermælken er afgrænset til brystet, opfattes den som sikker og ufarlig. Men når modermælken forlader kroppen rummer den en mulig forurening. Anskuet ud fra Mary Douglas' teori om orden og uorden (Douglas 1966) kan forarbejdningen af mælken i Kvindemælkcentralen anskues som en proces, der ved at adskille, rense og afgrænse sigter på at transformere urent til rent og derved etablere en ny orden. I det lille køkken er der stilhed, mens personalet, Rikke og Mia, præcist, sikkert og meget rutineret håndterer mælken. De omstændelige og omhyggelige processer vidner om, at både mælkens ernæringsmæssige betydning og dens økonomiske værdi for donorer og neontalafdelinger er vigtige for personalet.

Personalet gør meget ud af at fortælle Borring og Hansen, at mælken, som forarbejdes, er en blanding af forskellige kvinders mælk. Da Borring og Hansen spørger Anne Olin, hvorfor mødrenes mælk blandes, svarer hun:

"Det handler mest om, at vi standardiserer proteinniveauet. Men også fordi at de Europæiske retningslinjer siger 'Jamen vi skal ikke have min mælk til dit barn'." (Interview med Anne Olin, leder Kvindemælkcentralen, den 3/6 2016).

Der er således to logikker forbundet med at blande mælk fra flere mødre. For det første at sikre et standardiseret produkt og for det andet at sikre anonymisering og derved adskille mælken fra donormoren. Klaus Høyer og Maria Olejaz skriver i deres artikel Kroppens Politiske Økonomi om grænsedragning mellem person, krop og vare i medicinske udvekslingssystemer. Høyer og Olejaz anfører, at der ingen klare grænser er for hvornår og hvor længe, givne materielle elementer er en del af 
et menneske. Dermed kan disse elementer forstås som hybrider (Høyer og Olejaz 2011). I artiklen omtaler de "purifikationsarbejde" som det arbejde, der bestemmer, hvornår en substans er en del af et menneske, og hvornår en substans er ren materialitet uden menneskelighed (Høyer og Olejaz 2011). Det omstændelige kvalitetssikringsarbejde kan betragtes som purifikationsarbejde, hvorigennem Kvindemælkcentralen udvisker den direkte linje fra donormorens bryst til en anden mors barn. Denne udviskning bidrager til at gøre mælken til en neutral og banal materialitet, så mælken får karakter af en flydende væske, der kan flyde fra donor til ukendt barn. Modermælken beholder således sin oprindelige form, men ved at blande modermælken fra flere forskellige mødre omkonfigureres mælken af nye elementer, hvilket betyder, at mælken er i stand til at skabe nye relationer. Dog er det bemærkelsesværdigt, at den adskillelse og afgrænsning fra andre elementer, som purifikationsarbejde normalt indebærer, i Kvindemælkcentralen foregår ved at blande mødrenes mælk. Sammenblanding - det vil sige forurening - sikrer den fornødne anonymitet, som er udgangspunkt for, at forældre på neonatalafdelinger tager imod donormælk til deres barn. Gennem Kvindemælkcentralens purifikationsarbejde og de grænsesætninger, som forvaltes i forarbejdning af bankmælken, bliver mælken skabt som en sikker, brugbar og cirkulerbar substans, som muliggør mælkens rejse fra Kvindemælkcentralen til præmaturt barn. Mælkens flydende form er betinget af donormødrenes arbejde og selvdisciplinering i form af udmalkning af mælk samt hygiejne, og dette arbejde gør, at mælken er til rådighed i den bedst mulige kvalitet.

\section{Den naturlige standardisering}

Under vores feltarbejde bliver det hurtigt klart for os, at samspillet mellem forestillinger om "det naturlige" og "det standardiserede" er essentielt for neonatalmødrenes tilvalg af donormælk. Samtlige mødre fortæller os, at de allerede inden fødslen har besluttet, at de vil amme deres barn, hvis det er muligt. I overensstemmelse med den store vægt på amning i det danske sundhedsvæsen opfatter mødrene deres egen modermælk som den bedste og mest naturlige ernæring til deres barn (Sundhedsstyrelsen 2013, 11). Endvidere anser de amning som en god måde at skabe bånd mellem mor og barn på. Langt de fleste af de mødre, som ikke selv har mælk nok efter fødslen, takker ja til tilbuddet om donormælk. Maja, hvis barn er født i uge 30, forklarer: 
"Vi var blevet enige om, at det var donormælk, han skulle have, fordi det er det bedste for det for tidligt fødte barn. Så gjorde jeg mig egentlig ikke nogen tanker om, hvor mælken kom fra. Så længe det var fra et menneske, så kunne det være fra hvem som helst, for jeg går ud fra, som jeg også ved nu, at de undersøger det, og at det er i orden, det børnene får." (Interview med Maja, mor til et præmaturt barn, den 10/8 2016).

Maja lægger vægt på, at hun opfatter donormælk som det bedste alternativ til modermælk, fordi det er menneskemælk. Desuden udtrykker Maja tillid til sundhedsvæsnet og Kvindemælkcentralens sikkerhedsprocedurer. Hun stoler på, at donormælken er kontrolleret og derfor ikke kan skade hendes barn. I Borring og Hansens interview med neonatalmødrene spiller tilliden til sundhedsvæsnet og de sundhedsprofessionelle en stor rolle - ikke mindst i forældrenes valg af ernæring til deres præmature barn. Samtidig udtrykker neonatalmødrene en forestilling om, at det naturlige er det bedste for deres præmature barn. Signe, som er førstegangsmor til en lille pige født i uge 27 , forklarer:

"Alt, hwad der er lavet via naturens gang, må være meget bedre for børn end noget, der er kunstigt fremstillet. Erstatning er sammensat af nogle kunstige ting det er unaturligt for mig." (Interview med Signe, mor til et præmaturt barn, den 10/6 2016).

Samtidig med det store forarbejdningsarbejde af mælken, som udføres i Kvindemælkcentralen, anses donormælk blandt neonatalmødrene stadig som en "naturlig" substans, som vælges til på grund af dens naturlige egenskaber. Langt de fleste af neonatalmødrene udtrykker endvidere, at de ikke ville bryde sig om at tage imod modermælk, som kom direkte fra en anden kvindes bryst til deres barn - dette på trods af, at de alle giver udtryk for, at den naturlige mælk er den bedste. Majken, som er mor til en dreng født i uge 26, fortæller:

"Jeg ville nok blive lidt jaloux. Især i forhold til hois han fik en tilknytning til en anden kvinde, der ammede ham - også på grund af mælken. Fordi man giver noget af sig selv videre i mælken." (Interview med Majken, mor til et præmaturt barn, den 28/6 2016).

Majken anser den fremmede kvindes mælk som truende for forholdet til sin søn. Det, som truer Majken i hendes moderrolle, er ikke kun den intimitet, der ville 
blive skabt mellem den fremmede kvinde og Majkens søn, hvis kvinden ammede sønnen, det er også selve mælken, som er "farlig", fordi den bærer spor af en anden kvinde. Forestillinger om mælk som potentielt forurenende går mange århundrede tilbage. Før 1800-tallet var det i Storbritannien almindeligt at antage, at en amme gav mere end blot næring til barnet - også ammens ideer, overbevisninger, intelligens og alle hendes fysiske, mentale og følelsesmæssige træk blev overført til barnet. Ammen reproducerede således sig selv gennem barnet (Hogan 2008, 150). Ifølge antropologen Michael Jackson, som undersøger etiske dilemmaer ved medicinske teknologier, er organdonation associeret med en frygt for, at organmodtageren vil inkorporere personlighedstræk fra donoren. Således ønskes forsikring om, at det modtagne organ er klinisk sterilt - at det er symbolsk renset fra en beskidt verden af "ikke-jeg" (Jackson 2005, 136).

Neonatalmødrenes ønske om så naturlig mælk som muligt og deres samtidige oplevelse af mælk fra en anden kvinde som truende for forholdet til deres barn, får os til at undre os over, hvad mødrene forstår ved begrebet "naturlig". Mødrene opfatter det som FOR naturligt at lade en anden kvinde amme deres barn, da der følger følelsesmæssig "bonding" med amning, som de anser for unikt for relationen mellem mor og barn. De opfatter det også som FOR naturligt at tage imod udpumpet mælk fra en anden kvinde, hvis mælken ikke har været i kontakt med sundhedsvæsnet. På den anden side opfattes donormælken som naturlig på trods af, at den har været frosset, homogeniseret og pasteuriseret - processor, som er afkoblet fra kroppen og på den måde kunne opfattes som netop unaturlige. Den standardisering modermælken gennemgår i dens transformering til donormælk gennem hospitalets videnskab, teknologi og bureaukrati etablerer den nødvendige afstand for at skabe forbundethed. Adskillelse af uforarbejdet modermælk fra donor til modtager udvisker mælkens oprindelse i specifikke kroppe, hvilket gør det muligt for modtager at lade mælken være skaber af hendes forbundethed til eget barn. Neonatalmødrene ønsker et alternativ til egen mælk, som er skabt af en naturlig substans, men som er renset fra kvinden, som har produceret den - et standardiseret produkt uden følelsesmæssige bånd.

Det er kun, når modermælk gives til biologisk ubeslægtede børn, at den udsættes for kontrol, selv om patogener, der potentielt kan skade de præmature børn, lige så vel kan eksistere i mødrenes egen mælk og skade deres eget barn. Ifølge Carroll tyder dette på, at frygten for overførsel af sygdom ikke er den eneste grund til sikkerhed og risikostyring (Carroll 2014, 468). Tilsvarende peger Borring og Hansens empiri på, at sikkerhed og risikostyring også handler om at annullere forbindelsen til donormoderen, der opfattes som truende i forhold til modtager. 
Elizabeth Grosz (1994) arbejder med begrebet "abjekt" som det forkastede objekt, der engang var en del af kroppen. Abjekter er uden orden og kategori og betragtes derfor af Douglas som forurenende. Grosz udvider dog Douglas' begreber om, hvorledes kropsvæsker kan ses som farlige, når de krydser kroppens grænser og forstyrrer den sociale orden ved at stille spørgsmål til hierarkiet for kropsvæskers korrekthed (hierarchy of propreity). Grosz påpeger, at ethvert objekt er forskelligt rangeret efter en social og kulturel kontekst således, at hierarkiet for korrekthed regulerer dem (Grosz, 1994, s. 195). Nogle kropsvæsker såsom tårer, anses som rensende, mens opkast betragtes som meget forurenende. Da abjekter identificeres med det, som er »ikke-mig «, udgør abjekte substanser en fare for den legemlige integritet og truer med at opløse grænsen mellem "mig-selv" og "en-anden" (Shaw, 2004, s. 292). Mælken kan bringe donorens identitet med sig, og derfor er adskillelsen mellem mælk og donor potentielt utæt.

Ved at følge de konkrete praksisser får vi øje på, hvordan purifikationsprocesserne i Kvindemælkcentralen etablerer mælken som en substans, der kan udveksles, fordi den på en og samme tid både fremstår naturlig og renset fra donoren. Velfærdsstatens institutioner bliver dermed en instans, som bidrager til donormælkens naturlighed og får mælken til at fremstå neutral og standardiseret.

\section{Udvekslingsrelationer}

Fælles for alle donormødre i vores studie er, at udmalkning fylder meget i deres liv som nybagte mødre. Mange af dem har selv være indlagt på neonatalafdelingen med for tidligt fødte børn. Maria, som er mor til tre små piger, der alle er født for tidligt, og som alle har modtaget donormælk, indtil Marias egen mælkeproduktion kom i gang, fortæller om sin motivation:

"Så tænkte jeg bare, at man lige så godt kan hjelpe nogle andre, ligesom jeg selv havde fäet hjælp." (Interview med Maria, donormor, den 7/7 2016).

Maria ønsker at gengælde den ydelse og hjælp, hun og hendes familie selv har modtaget fra andre mødre - en hjælp, hun har modtaget gennem det offentlige sundhedsvæsen. Selve begrebet "mælkebank" associerer, at man sætter ind eller donerer for senere at kunne hæve eller indkassere. Eller i omvendt rækkefølge som vi oftest erfarer: Man hæver for senere at betale tilbage. Under vores samtaler med donormødrene viser det sig, at alle de donormødre, som har ligget på neo- 
natalafdelingen, har samme tilgang til donation af mælk, som Maria. Vi sporer en solidaritet med et socialt fællesskab af både præmature børn, deres forældre og tidligere donorer. Ved at donere deres modermælk praktiserer kvinderne et civilt ansvar og placerer sig i relation til fremtidige borgere, som kan få brug for ernæring i form af den mælk, de kan tilbyde. Vi ser, hvordan Kvindemælkcentralen muliggør og forvalter dette forpligtende fællesskab, og hvor stor en indsats personalet i Kvindemælkcentralen gør for at drage omsorg for donormødrene som en del af statens omsorg for borgerne.

Donationen af modermælk giver neonatalmødrene en mulighed for at praktisere gensidighed. Vores studie demonstrerer således en generaliseret udveksling (Lévi-Strauss 1969), hvor gaven, der gives, ikke gengældes af den samme person, men tværtimod returneres af andre personer og med en tidsforskydning mellem gaverne. Mødrene, Borring og Hansen interviewer, ønsker at bidrage med mælk til fremtidige børn, da årsagen til, at deres børn har kunnet få donormælk, da de var indlagt på neonatalafdelingen, var, at andre mødre på et tidligere tidspunkt havde doneret deres mælk. Donormødrene oplever donationen af mælk som en del af det civile ansvar, der ligger i at betale tilbage til kollektivet. Et kollektiv som består af andre borgere (mødre), der har bidraget med mælk, personalet i Kvindemælkcentralen, som etablerer mælk som brugbar substans, og det offentlige sundhedsvæsen, som orkestrerer hele udvekslingsrelationen. Gennem donation og modtagelse af mælk skabes der forbundethedsrelationer til et forpligtende fællesskab, hvor Kvindemælkcentralen står som forvalter.

I vores samtaler med donormødre, der har født sunde og raske børn, og som intet kendskab har til livet på en neonatalafdeling, oplever vi ikke den samme følelse af pligt. Alligevel er lysten til at hjælpe andre den primære grund til, at disse mødre vælger at donere. Kamilla, som er førstegangsmor til en dreng på fire uger, beskriver sin bevæggrund for at donere mælk således:

"Jamen, jeg synes jo, at det er dejligt, at sådan nogle små nye nogen får mulighed for at få det bedste - den bedste start. Også hvis man selv en dag får et for tidligt født barn, at der så er nogle andre, der har gjort det samme. Det vil man jo være dybt taknemmelig for." (Interview med Kamilla, donormor, den 11/8 2016).

Forestillingen om at kunne modtage med god samvittighed, hvis Kamilla skulle stå i samme situation en dag og have brug for donormælk, beror på en ide om, at hvis man ønsker at modtage mælk, så må man også selv være villig til at donere. Dette illustrerer Kamillas tanker om, hvordan hun forestiller sig et medlemskab af 
kollektivet. Ifølge Jackson er måden, vi som mennesker tænker og agerer på, rodfæstet i oplevelser af socialitet, særligt reciprocitet (Jackson 2005). Da vi spørger donormødrene, om de gør sig nogle tanker om, hvem de donerer til, og hvor mælken ender, svarer langt størstedelen dog nej. Donationen af mælk bliver således meningsfuld for mødrene ved at bidrage til et uspecifikt fællesskab frem for, at donationen anses som gaver til bestemte personer. Denne diffuse og upersonlige form for forbindelse mellem donor og modtager giver mening for alle parter i udvekslingen. Grænserne mellem donorer og modtagere, som purifikationsarbejdet etablerer, muliggør den enkeltes forbundethed med et større anonymt kollektiv (Svendsen 2007).

Enkelte donormødre omtaler den økonomiske gevinst, der er ved donation af modermælk. Alligevel opfatter vi ikke penge som værende det væsentligste motiv for at donere. Karen fortæller:

"Når nu jeg havde rigelig mælk, hvis jeg så kunne hjælpe nogle andre, så var det en bonus, og hvis jeg så ovenikøbet fik penge for det, så var det dobbelt bonus. Så jeg kunne ikke finde noget, der talte imod at gøre det. Der skal bare være mælk til rådighed til dem, der skal bruge det." (Interview med Karen, donormor, den 3/8 2016).

Karen omtaler pengeaspektet som en ekstra gevinst, der ikke gør hendes gerning mindre værd. For hende er det relevant, at der er mælk til rådighed til dem, som har et behov. Louise, som er mor til to børn født til tiden, udtaler i vores interview: "Det er jo rart at tjene penge på at undgå at få brystbetændelse." Men selvom Louise indledningsvis giver udtryk for, at hun primært er drevet af de økonomiske incitamenter, italesætter hun senere i interviewet donationen som vigtig for sin identitet som mor. Louise siger:

"Man kan jo lige så godt hjelpe dem, altså de for tidligt fedte og de, som har ekstra brug for det. Det er meget fedt som mor at kunne det. Altså hjelpe!" (Interview med Louise, donormor, den 12/7 2016).

Donationen af mælk støtter således Louise i hendes rolle som mor. Når man er mor, er det noget man gør, man hjælper. Donation af mælk formes af moralske motiver, hvor donation af mælk fremstår som en ansvarlig og samvittighedsfuld handling, som er med til at konstituere donoren både som den gode mor og den gode medborger. I sit studie af donation af embryoner til fremtidig forskning ar- 
gumenterer Svendsen for, at donation skaber et handle- og mulighedsrum for de par, der deltager. Svendsen viser, at donationen af embryoner for flertallet af hendes informanter handler om at være en god borger og gøre det rigtige i den situation, parrene står i (Svendsen 2007, 181-203). Dog synes hendes informanter ikke, at en udveksling af embryoner kunne finde sted i en markedsbaseret relation, hvor man som donor blev betalt. Det samme finder Klaus Høyer og Niels Lynöe i deres studie i Sverige, hvor de observerede bloddonationssituationer samt foretog interviews med bloddonorerne i forbindelse med samtykke til videregivelse af blodprøver til biobanker (Høyer og Lynöe 2006). Svendsen samt Høyer og Lynöe hævder, at der eksisterer gensidigt forpligtende relationer mellem borger og stat i de skandinaviske velfærdssamfund, som gør, at beslutningen om donation snarere træffes grundet de forpligtende relationer end på baggrund af et rationelt valg baseret på informationer. I vores felt synes de moralske handlinger og den økonomiske værdi ikke at være modstridende, da donation af mælk ikke mister sin værdi som god gerning på trods af, at mødrene betales for mælken.

Motivet for at donere mælk for alle donormødrene beror på et ønske om at gøre en god gerning eller give noget igen, som man enten selv har fåt gavn af eller måske $\mathrm{i}$ fremtiden kommer til at få gavn af. På den måde placerer mødrene sig selv i en tidslig udveksling af ressourcer, som opretholder velfærdskollektivet. Kvindemælkcentralen etablerer det handlerum, hvor mælken som substans skaber en forbundethed til et fællesskab af både donorer, personalet i Kvindemælkcentralen og neonatalmødrene.

\section{Konklusion}

Kvindemælkcentralens eksistens og arbejde er et resultat af samfundets syn på børn og nye liv. Det er en institution, som muliggør transformation af modermælk, der er af fundamental betydning for det for tidligt fødte barns udvikling, både ernæringsmæssigt samt følelsesmæssigt, til donormælk, som er en standardiseret ressource med elementær ernæringsmæssig betydning for barnet. Gennem udveksling af mælk forbinder Kvindemælkcentralen borgere til et velfærdskollektiv, som både består af offentlige institutioner og andre fremtidige medborgere. For alle aktører repræsenterer det nyfødte barn en kontinuitet af liv, slægt og samfund og ved at bidrage til dette barn, indlemmes de også selv i et samfundsfællesskab.

Ved at udforske modermælkens transformation til donormælk opdager vi, hvor komplekst et socio-teknisk netværk af genstande og aktører donormælk indgår i 
med mælkeproducerende mødre som givere, det offentlige sundhedssystem som mediator og mødre af præmature børn som modtagere. Ved at følge de forhandlinger, substansen gennemgår, synliggøres, at modermælk kan antage forskellige former alt efter, hvilket rum den indgår i samt hvilke aktører, der håndterer den. Mælken fremstår som en substans, der flyder over fra mor, og som kan opsamles af Kvindemælkcentralen, hvorefter mælken flyder fra bank til modtager. Samtidig indebærer betalingen for modermælk, at mælken fremstår som en målbar enhed, hvis mængde afgør et økonomisk beløb, som afslutter transaktionen mellem bank og donor, og som kun indirekte implicerer præmature og syge børn.

Etnografien viser, at mælken etablerer forbindelse mellem barn og mor og mellem individ og samfundskollektiv. Grænsedragningerne i form af anonymiteten i donationspraksissen samt det purifikationsarbejde, som personalet i Kvindemælkcentralen udfører, er afgørende for mobiliseringen af forbundethedsrelationer. Etableringen af mælk, som flyder mellem donor og modtager, sker gennem grænsesætninger og økonomiske transaktioner. Mælkens flydende form er betinget af en række tjekpoints, hvor mælken tager form af en vare mellem anonyme personer. Både donormødre og neonatalmødre indgår i et velfærdskollektiv, hvor det for begge parter er vigtigt, at kollektivet fremstår anonymt og uden konkret forbindelse til hverken den specifikke donor eller modtager af mælk. Således etablerer Kvindemælkcentralen det handlerum, hvor reciprocitetsrelationer mellem stat og borger kan eksistere og plejes, og hvor donationen af mælk skaber en forbundethed med et anonymt kollektiv af tidligere og fremtidige brugere samt det offentlige sundhedsvæsen.

\section{Noter}

${ }^{1}$ Sacralization er et begreb udarbejdet af Zelizer, der refererer til "genstande der investeres i sentimentalt eller er af religiøs betydning" (Zelizer 1985).

${ }^{2}$ Priser baseres på feltarbejde juni 2016. Beløbet er udregnet af hospitalets økonomer og baseret på konceptet af Kvindemælkcentralen som en "nulbutik", der ikke bør generere overskud (Interview Anne Olin, 2/11 2016). 


\section{Referencer:}

Arnold, Louis. »Donor Milk Banking in Scandinavia.« J Hum Lact, 1999: 55-59. https://doi. org/10.1177/089033449901500117

Boyd, Catherine A, Maria A Quigley, and Peter Brocklehurst. »Donor breast milk versus infant formula for preterm infants: systmatic review and meta-analysis." Arch Dis Child Fetal Neonatal, 92 2007: F169-F175. https://doi.org/10.1136/adc.2005.089490

Boyer, Kate. „Of care and commodities: breast milk and the new politics of mobile biosubstances.« Progress in Human Geopraphy, 2010: 5-20.

Carroll, Katherine. »Body dirt or liquid gold? How the 'safety' of donated breastmilk is constructed for use in neonatal intensive care.« Social Studies of Science, 44(3) 2014: 466485. https://doi.org/10.1177/0306312714521705

Carsten, Janet. »The Substance of Kinship and the Heat of the Hearth: Feeding, Personhood, and Relatedness among Malays in Pulau Langkawi.« American Ethnologist, 22(2) 1995: 223-241. https://doi.org/10.1525/ae.1995.22.2.02a00010

Carsten, Janet. Cultures of Relatedness. New Approaches to the Study of Kinship. Cambridge: Cambridge Univrsity Press, 2000.

Douglas, Mary. Purity and Danger. An analysis of the concepts of pollution and taboo. New York: Routledge, 1966.

Grosz, Elisabeth. Volatile Bodies: Towards a Corporeal Feminism. Bloomington: Indiana University Press, 1994.

Grøvslien, Anne Hagen, and Morten Grønn. »Currents in Human milk Banking. Donor Milk Banking and Breastfeeding in Norway.«J Hum Lact, 25(2) 2009: 206-10. https://doi. org/10.1177/0890334409333425

Hogan, Susan. »Breasts \& the Beestings: Rethinking Breast-Feeding Practices, Maternity Rituals, \& Maternal Attachment in Britain \& Ireland.« Journal of International Women's Studies, November 2008: 141-160.

Høyer, Klaus. »Hvem ejer cellerne?« In Håbets tekonologi. Samfundsvidenskabelige perspektiver på stamcelleforskning i Danmark, by Lene Koch and Klaus Høyer, 93-110. København: Munksgaard Danmark, 2007.

Høyer, Klaus, and Maria Olejaz. »Kroppens politiske økonomi.« Kulturstudier, December vol 2, 2011: 157-177.

Høyer, Klaus, and Niels Lynöe. »Motivating donors to genetic research? Anthropological reasons to rethink the role of informed consent. Medicine, Healthcare and Philosophy, 9 2006: 13-23. https://doi.org/10.1007/s11019-005-5067-1

Jackson, Michael. Familiar and Foreign Bodies. In Existential Anthropology - Events Exigencies and Effect. New York: Berghan Books, 2005. https://doi.org/10.2307/j.ctt1x76f0c.12

Lévi-Strauss, C. »The Principle of Reciprocity.« In the Elementary Structures of Kinship, by R. Needham, 56-68. Oxford: Alden Press, 1969.

Mol, Annemarie. The Body Multiple. Duke University Press, 2002. https://doi. org/10.1215/9780822384151

Mol, Annemarie, and John Law . »Regions, Networks and Fluids: Anaemia and Social Topology.« Social Studies of Science, Nov. Vol. 24, No. 4, 1994: 641-671.

Pedersen, Jens Kruse. »The Woman Milk Bank at Fuglebakken Children's Hospital.« Danish Medicin Bulletin, Oct 29(6), 1982: 300-305. 
Shaw, Rhonda. »The virtues of cross-nursing and the 'yuk factor1. « Australian Feminist Studies, 19:45 2004: 287-299. https://doi.org/10.1080/0816464042000278972

Sundhedsstyrelsen. Amning - en håndbog for sundhedspersonale. København: Sundhedsstyrelsen, 2013.

Sundhedsstyrelsen. Ernæring til spædbørn og småbørn - en håndbog for sundhedspersonale. København: Sundhedsstyrelsen, 2016.

Svendsen, Mette Nordahl. »Mellem reproduktiv og regenerativ medicicn. Donation som handlerum i fertilitetsklinikken. «In Håbets teknologi. Samfundsvidenskabelige perspektiver på stamcelleforskning i Danmark, by Lene Koch and Klaus Høyer, 181-206. København: Munksgaard Danmark, 2007.

Thomaz, Pimenteira AC, et al. »The Human Milk Donation Experience: Motives, Influencing Factors, and Regular Donation.«J Hum Lact, Feb 24 (1), 2008: 69-76.

Tully, Mary Rose. »Currents in human milk banking. Human Milk Banking in Sweden and Denmark.« J Hum Lact, 7(3) 1991: 145-146. https://doi.org/10.1177/089033449100700324

Waldby, Catherine, and Robert Mitchell. Tissue Economies. Durham and London: Duke University Press, 2006. https://doi.org/10.1215/9780822388043

Zelizer, Viviana. Pricing the Priceless Child. New York: Basic Books, Inc., 1985. 